\title{
혁신적 개발재원 조성 (Innovative Financing for Development): 개념의 발전과 동향1)
}

목차

I. 서론

II. 혁신적 개발재원 조달의 논의 배경과 흐름

III. 혁신적 개발재원 조달 개념의 발전

1. 혁신적 개발재원 조달 개념 정의

2. 혁신적 개발재원 조달 개념의 발전

IV. 혁신적 개발재원 조달의 유형별 사례

$\mathrm{V}$. 결론

참고문헌

1) 본 원고는 KOICA에서 발간 예정인 ‘혁신적 개발재원 조성을 위한 국제사회 동향연구(가제)'에 일부 수록될 예정임을 미 리 밝힌다. 


\section{I. 서론}

$\mathrm{SDGs}$ 논의가 진척될수록 목표의 이행 및 달성을 위한 개발재원 조달의 논의 역시 활발해지고 있다. 최근 개발재원 논의에서 뜨거운 이슈로 떠오른 것이 바로 '혁신적 개발재원 조달(innovative financing for development 혹은 innovative development financing)'에 관한 개념과 사례에 대한 것이다. 2002 년 제 1 차 개발재원총회를 기점으로 혁신적 개발재원 조달에 대한 논의는 시작 되었으며, 이후 동 개념의 정의, 유형 및 사례에 대해서 $\mathrm{UN}, \mathrm{OECD}$, 세계은행 및 여러 공여기관 들에서 제시하게 되었다. 각각의 기관마다 제시하는 정의는 조금씩 차이가 있으나, 공통적으로 나 타내는 특징들 또한 발견되었다. 뿐만 아니라, 시간의 흐름에 따라 동 개념의 정의 또한 변화되어 왔다. 따라서 이번 원고에서는 최근 많은 관심을 받고 있는 혁신적 개발재원 조달 논의의 등장 배경 및 흐름을 살펴봄으로써 해당 개념의 정의와 유형이 어떻게 변화해왔는지 알아봄으로써 개 발재원 논의에 있어 '혁신적(innovative)'이 무엇을 의미하는지를 명확히 파악하기로 한다.

\section{II. 혁신적 개발재원 조달2)의 논의 배경과 흐름}

개발재원을 혁신적인 방식을 통해 조달하자는 논의는 2002년 몬테레이에서개최된 제1차 개발 재원총회에서 처음 시작되었다. 새천년개발목표(MDGs) 달성을 위한 개발재원 확대 방안을 논의 한 동 회의의 결과문서인 몬테레이합의(Monterrey Consensus)문서를 살펴보면, 여러 조항에서 혁신적 개발 재원 조달(innovative development financing)에 대한 언급을 통해 그 중요성을 드러내고 있다. 먼저, 해외직접투자 및 기타 민간재원 흐름을 포함한 개발 목적의 국제자원 동원 을 위해 혁신적 개발재원 조달을 촉진해야 하며 이를 위해 개도국 및 선진국의 은행과 기타 금융 기관의 참여를 이끌어내야 함을 명시하고 있다. 또한, 국제개발협력 분야에 있어서 역시 개도국에 지나치게 부담을 주지 않는 선에서 혁신적 개발재원을 탐색하는 것의 중요성을 언급하였으며, 각 국가의 서로 다른 경제 상황 및 역량을 고려하였을 때 여러 수단이 적절히 혼합이 필요함을 인지 하고 있음을 밝혔다. 개도국의 부채 문제를 종합적으로 해결하기 위한 혁신적 메커니즘 모색을 강조한 동 회의는 개발재원의 중요성 뿐만 아니라 재원 조달을 위한 혁신적인 방식에 대한 국제

2) 본 고에서는 국제 논의에서 주로 활용되는 'Innovative development financing' 혹은 'Innovative financing for developmen'라는 용어를 financing을 '혁신적 개발재원 조달이라는 용어로 번역하였다. 파이낸싱(financing)은 특정 목표 를 달성하기 위한 자금을 지원하는 것을 포함하여 은행대출, 유치기여 및 후원자 및 투자자를 찾아내는 재원 조달의 ‘활 동'을 의미하며, 이는 '재원(finance)'와는 다른 개념이라는 것이라는 것을 밝힌다. 
적 관심을 이끌어내기 시작한 회의였다.

그 이후 본격적으로 혁신적 개발재원 조달에 관한 논의가 구체화되어 가기 시작하였다. 첫 번 째 작업은 $\mathrm{UN}$ 사무총장의 지원 하에 브라질, 칠레, 프랑스, 스페인의 대통령이 공동으로 제안하 여 이루어졌다. 2003년 10월 프랑스 대통령의 요청에 따라 자문 그룹을 설립하고 경제적 재무적 실현가능성이 입증된 몇 가지의 혁신적 재원 조달 메커니즘을 파악하는 작업을 하였으며, 이는 2004년 1월 프랑스, 브라질, 칠레, 스페인, 독일, 알제리로 구성된 '6개 그룹'의 보고서를 통해 제시되었다. 이후, 이들 리더들은 2004년 9월 뉴욕에서 열린 기아와 빈곤 퇴치 이니셔티브의 일 환으로 첫 번째 혁신적 개발재원 조달과 관련한 범정부 정책대화를 통해 기아와 빈곤 퇴치 및 개 발 증진은 정치적 약속과 개발재원조달의 간극을 긴급히 메우지 않는 한 달성되지 않을 것임을 언급하였고, 혁신적 개발 재원 조달의 구체적 이행을 위해 2004년 9월 '혁신적 개발재원 조달 메

제 I 장

개 커니즘에 관한 전문가그룹보고서(Report of the Technical Group on Innovative Financing Mechanisms)'를 발표하였다.

동 보고서는 2004년 1월 30일 제네바 선언에 의해 설립된 전문가 그룹이 준비한 보고서로서 혁신적 개발 재원 조달의 방식으로 크게 3가지를 제안하였다. 첫째, 의무적 메커니즘(mandatory mechanism)으로는 금융거래세(taxation of financial transactions), 무기거래세(taxation of the arms trade), 국제금융기금(international financial facility), 개발재원 특별인출권(SDR for financing development)3)이 있으며, 둘째, 정치적 협조(political coordination)에 있어서 는 조세 회피와 조세피난처 그리고 송금의 혜택 증진을 제시하였다. 마지막으로 자발적 메커니즘 (voluntary mechanism)에서는 신용카드를 통한 자발적 기여(voluntary contributions through credit cards)와 사회책임투자 혹은 윤리적 펀드(ethical funds)를 제시했다. 2004년 9월에 뉴욕 유엔 본부에서 열린 기아와 빈곤 퇴치행동에 관한 정부 수반 회의에서 브라질 룰라 대통령의 이 니셔티브로 동 선언은 107 개 국가들에 의해 지지를 받았다.

2005년 9월 뉴욕에서 열린 밀레니엄 정상회담(Millennium Summit)에서는 '개발을 위한 혁신적 재원 조달에 관한 선언(Declaration on Innovative Sources of Financing for Development)' 이 발표됐다. 선언의 내용으로는 브라질 룰라 대통령의 이니셔티브로 인해 해당 논의가 시작되었음 을 언급하며, $\mathrm{ODA}$ 는 여전히 빈곤국의 개발 전략에 있어 필수적 요소이지만, 향후 보다 많은 자원 이 필요함에 따라 혁신적 개발재원 마련이 중요함을 강조하였다. 이의 일환으로 특별인출권(SDR) 의 할당, 민간의 자발적 기여 촉진과 더불어 영국정부가 제안한 국제금융기금(International Financial Facility, 이하 IFF)을 지속적으로 고려할 것이며, 개발 재원 조달 시스템 내 요소로서

3) IMF의 특별인출권을 말하는 것으로서 SDR은 IMF에서 창설되어 IMF가맹국이 규약에 정해진 일정조건에 따라 IMF로부터 국제유동성을 인출할 수 있는 권리를 말한다. 
국제 조세를 신설하는 것을 지원함을 밝혔다. 구체적으로는 브라질, 칠레, 프랑스와 독일에 의해 제안된 항공권 연대 기여금 프로젝트를 위해 지속적으로 노력할 것임을 언급하였다. 동 선언문은 $\mathrm{EU}$ 국가, 브라질, 인도, 개도국 등 97 개 국가에 의해 지지받은 바 있다.

2006년에는 2월 28일부터 3월 1일까지 양일간 프랑스 대통령이 이니셔티브를 이어받아 '혁신 적 개발재원 메커니즘에 관한 파리 회의(Paris Conference on Innovative Development Financing Mechanism)'가 개최되었다. 동 회의는 장관급 국제회의로써 새로운 개발재원 조달 메커니즘, 구체적으로는 국제 연대기여금 이행, 현재 기획 중인 항공권 연대기여금에 대한 강화 및 기여금을 유행성 질병 퇴치 등을 위해 사용하는 가능성 여부에 있어 합의를 이루고자 하는 목 적으로 개최되었다. 2005년 9월 14일에 뉴욕선언에서 서명한 약 100개 국가 이상에서 참여한 동 회의에서 프랑스 정부는 2006년 7월 1일부터 항공권 연대기여금을 신설함으로써 이를 실현화시 킬 것을 언급하였으며, 기여금을 개도국 내 전염성질환 퇴치에 사용할 것임을 밝혔다.

이는 '개발을 위한 혁신적 개발재원 조달 리딩 그룹(Leading group on Innovative Financing for Development)'을 창설하는 계기가 되었으며, 동 그룹은 혁신적 개발재원 조달 메커니즘의 구현을 실현화하게 되었다. 리딩그룹은 초기에는 '개발 재원 마련을 위한 연대부담금 리딩그룹 (Leading Group on Solidarity Levies to Fund Development)'이라는 이름으로 2006년 3월 1 일 설립되었다.

\section{〈상자 1〉혁신적 개발재원 조달 리딩그룹의 소개}

$\square$ 리딩그룹 의장직(Presidency of Leading Group): 리딩그룹은 매년 서로 다른 국가가 의장직을 수행하며, 2014-2015년 의장직은 칠레에서 수행하였음. 의장은 지원한 후보자들 중 합의에 의해 결정되며, 지역적 순환 원 칙을 따름. 의장의 책임으로는 (1) UN 내에 혁신적 개발 파이낸싱 증진을 위한 리더로써 활동하며, 리딩그룹의 메 시지를 국제사회에 알리는 대변인 역할을 함; (2) 매년 영구적 사무국인 프랑스와 협력하여 워크프로그램을 수립 함; (3) 임기 마지막 총회세션을 조직하고 주최함.

영구적 사무국(Permanent Secretariat): 2006년 파리회의를 기점으로 설립된 이래, 프랑스(외교부)가 그룹의 영구 적 사무국을 담당하고 있음. 이는 프랑스가 리딩그룹에 참여하는 행동네트워크를 조정하고, 순환 의장과 함께 작 업 주제를 제공하고, 회의와 이벤트의 로지스틱스를 지원함.

참가국 (회원국 및 옵저버): 총 66개국이며, 우리나라 역시 회원국으로 2007년에 의장직을 수행한 바 있음. 또한, 여러 국제기구 및 개발은행, 자선재단 및 기업, 비정부기구들 역시 함께 논의에 참여하고 있음.

출처: 리딩그룹 홈페이지

리딩그룹의 목표로는 혁신적 개발재원 조달 분야에서의 프로젝트의 수립 및 이행에 기여하고, 관련 파트너와 포럼 등에서 연대부담금의 아이디어를 촉진시키며 국제항공권 연대기여금을 발전 시키고 동 기여금을 보건 개발 분야에 활용, 국제약품구매기금(International Drug Purchase 
Facility)의 이행 모달리티 수립 등이 있다. 현재의 이름은 2009년 6월에 변경된 것으로서, 그룹 명의 변경은 해당 논의가 연대부담금에서 다양한 메커니즘으로 확장되었다는 것을 시사한다고 보 여진다. 동 그룹에서는 2006년에 첫 번째 혁신적 개발재원 조달 메커니즘으로서 국제금융면역백 신기구(International Finance Facility for Immunisation, 이하 IFFIm)과 국제의약품구매기구 (UNITAID)를 설립하였으며, 혁신적 개발재원 중 항공권 연대기여금, 선시장약정(Advance Market Commitment, 이하 AMC), debt2health 등이 동 그룹을 통해 실행되었다.

이후 2008년 도하에서 열린 제2차 개발재원총회에서는 혁신적 개발재원 조달에 대해 구체적으 로 논의하게 되었다. 동 회의의 결과문서인 '개발을 위한 재원조달에 관한 도하선언(Doha Declaration on Financing for Development)'을 살펴보면, 몬테레이 이후 혁신적 개발재원 조 달과 관련하여 활발한 논의가 있었음을 알 수 있다. 해당 문서에서는 몬테레이 이후 동 논의에 대한 상당한 진전이 있었음을 언급하며 전문가 그룹과 리딩그룹의 창설과 이들로 인한 IFFIm, $\mathrm{AMC}$, 항공권 연대기여금, UNITAID 설립 등 국제 보건 문제를 해결하기 위한 노력들을 인지하 고 있음을 밝혔다. 그 외에도 여러 국가에서 시행된 이니셔티브들을 언급하며, 이들은 전통적 개 발재원의 보완재로서의 역할을 해야 하며, 대체제가 되어서는 아니됨을 명확히 했다. 또한, 재원 의 사용은 개도국의 개발전략 우선순위와 일치해야 하며, 개도국에게 지나친 부담으로 작용해서 는 안 된다는 것 역시 제시했다. 추가적으로는, 현재 이니셔티브를 포함해 향후에도 새로운 제안 들을 지속적으로 해줄 것을 국제사회에 요청하였다. 양- 다자간 은행에 저소득국, 중소득국, 경제 전환국 등 각 국가의 상황에 따라 추가적으로 재원이 동원될 수 있는 혁신적 메커니즘을 탐색할 것을 요청하였으며, $\mathrm{ODA}$, 보증, 민관협력(PPP)등이 민간재원을 동원하기 위한 촉매제로서 역할 을 할 수 있음을 언급했다. 도하선언은 몬테레이합의와 비교해 볼 때, 혁신적 개발재원 조달에 대 해 보다 강조를 하고 있음을 문서에서 차지하고 있는 비중뿐만 아니라 내용의 구체성을 통해서도 알 수 있었다. 이는 혁신적 개발재원 조달에 관한 논의가 확장되고 있음을 보여주고 있으며, 특 히, 도하선언 이전에 혁신적 개발재원 조달 메커니즘은 주로 새로운 재원 원천을 마련하기 위한 것에 중점을 두었던 반면, 민간재원을 추가적으로 동원하기 위한 메커니즘에 대한 언급이 있었다 는 것 역시 특징이라고 볼 수 있겠다. 
〈표 1〉|-8 Group의 8가지 혁신적 개발재원 조달 메커니즘

\begin{tabular}{c|l}
\hline 혁신적 메커니즘 & \multicolumn{1}{c}{ 설명 } \\
\hline UNITAID & $\begin{array}{l}\text { 2006년 설립 이후 클린턴재단과의 파트너십으로 제약회사와의 협상을 통해 AIDS 약품가격 } \\
50 \% \text { 감소시켰으며, HIV 치료를 받은 4명 어린이 중 3명은 UNITAID의 혜택을 받음. }\end{array}$ \\
\hline IFFIm-GAVI & $\begin{array}{l}\text { 국제면역금융기금(the International Finance Facility for Immunization)은 2006년 영국정부 } \\
\text { 의 이니셔티브로 설립되었으며 영국, 프랑스 노르웨이, 이탈리아, 스웨덴, 남아프리카공화국, } \\
\text { 스페인 국가 장기 차입역량을 활용하여 시장에서 자금을 모으고 GAVI Alliance 하 전세계 } \\
\text { 70여개 빈곤국 내 면역 프로그램에 자금을 지원함. 향후 20년 간 40억 달러를 모금하는 } \\
\text { 것이 목표이며, 2010년 현재 10억 달러 이상을 조달함. }\end{array}$ \\
\hline AMMC & $\begin{array}{l}\text { AMC난 개도국 내 개발목적의 백신생산을 위한 자금을 제공하는 메커니즘으로 공여기관들 } \\
\text { 은 백신이 개발되는 즉시 백신가격의 보증을 약정함. 따라서, 지속가능한 시장의 창출을 위 }\end{array}$ \\
한 근본이 되며, 이러한 약정은 생산자들이 연구, 스텝ㅂ 교육 및 생산시설에 상당한 투자를 \\
하는 데 있어 필수적 인센티브로 작용함.
\end{tabular}

출처: 1-8 Group (2009) 참고하여 저자 작성

2009년에는 UN 사무총장 특별자문관이자 UNITAID 의장인 Philippe Douste-Blazy을 중심 으로 하여 8가지의 혁신적 개발재원 조달 메커니즘 연합인 I-8 Group Leading Innovative Financing for Equity (L.I.F.E)이 발족하였다. I-8 Group은 기존의 혁신적 메커니즘을 강화하 고 새로운 메커니즘을 탐색하기 위한 필요성에 의해 창설되었으며, UNITAID, IFFIm-GAVI, AMC, UNITAID를 위한 자발적연대기여금, product RED와 Global Fund, Debt2Health, 탄소 시장, 사회책임투자(socially responsible investments)로 구성되었다.

최근에는 2014년 세계경제포럼(WEF)과 OECD가 공동으로 주최한 '개발재원 리디자이닝 이니 셔티브(Redesigning Development Finance Initiative)'에서 혁신적 개발재원으로서의 혼합재원 
조달(blended financing)이 소개되었다. 세계경제포럼과 $\mathrm{OECD}$ 는 혼합재원조달의 개념을 이머징 및 프런티어 시장에서의 민간 자본 유입 동원을 위한 개발 재원과 자선기금의 전략적 사용이라고 정의한다. 혼합재원의 조달은 위험조정수익(risk-adjusted returns)을 제공하는 동시에 의도적으 로 개발 영향이 높은 부문에 민간 투자를 연결하는 것을 의미한다.

이어서 2015년 아디스아바바에서 열린 제3차 개발재원총회 결과문서인 아디스아바바행동의제 (Addis Ababa Action Agenda, AAAA)에서 역시 혁신적 개발재원의 중요성이 언급되었다. 아 디스아바바행동의제 제69항에서는 몬테레이합의 이후 '혁신적 개발재원 조달을 위한 리딩그룹 (Leading Group on Innovative Financing for Development)' 등에 의해 추가적인 재원 마련 의 혁신적 원천 및 방법에 대한 지원을 개발하고 동원하는데 이뤼진 진척을 환영하고 있다. 보다 많은 국가들을 대상으로 개발도상국에 지나친 부담을 주지 않는 혁신적 메커니즘, 수단 및 지원 방식을 자발적으로 실행하기를 요청하면서 국제백신금융기금(IFFIm)과 같은 기존의 메커니즘을 활용한 것을 권장하였다. 또한, 녹색채권, 백신채권, 풀메커니즘(pull mechanism)4)및 탄소가격 메커니즘과 같은 공적 및 민간자원을 결합하는 모델에 기초하여 추가적인 혁신적 메커니즘을 탐 색 역시 권고하고 있다.

뿐만 아니라 아디스아바바행동의제에서도 강조됐던 민간재원의 동원 이슈에 있어서는 다양한 민간재원을 필요한 개발목적에 적합하게 동원하기 위해서 여러 유형의 혁신적 금융수단이 필요하다 는 논의가 활발히 진행되고 있다. 2016년 2월 $\mathrm{OECD} \mathrm{DAC을} \mathrm{중심으로} \mathrm{이들을} \mathrm{논의하기} \mathrm{위한} \mathrm{동료}$ 학습 워크숍이 '개발협력에서의 민간부문과의 협력을 통한 혁신적 수단(Innovative Instruments for Working with and through the Private Sector in Development Co-operation)'을 주 제로 개최되기도 하였다. 동 워크숍에서는 혁신적 금융 수단을 활용한 민간협력 여러 사례들이 소개되었으며, 대표적인 사례는 덴마크기후투자펀드(Danish Climate Investment Fund), 아프 리카보증펀드(African Guarantee Fund), 미국의 개발금융기관인 OPIC의 임팩트투자(Impact Investing), 글로벌혁신펀드(Global Innovation Fund), EU 혼합 프레임워크(EU Blending Framework), USAID의 보증 수단을 활용한 프로그램인 Development Credit Authority 등이 있다.

4) 풀메커니즘은 민간부문이 설정된 목표를 향해 노력하도록 촉진하는 방식으로써 증여모델을 활용하는 전통적 개발 방식과 는 대조적으로 개발목표에 대한 특정 진로를 결정하기 위해서 구체적 투입과 절차보다는 사전에 확정된 결과 달성에 대 해 보상한다. 또한, 이러한 결과 달성에 포함된 전략 및 기술에 대한 선호도는 고려하지 않는 방식을 말한다. 


\section{III. 혁신적 개발재원 조달 개념의 발전}

\section{1. 혁신적 개발재원 조달 개념 정의}

최근 새롭게 제시되는 개발협력 분야의 개념들과 마찬가지로 '혁신적 개발재원 조달(innovative financing for development)'의 개념 역시 국제적으로 합의된 정의는 존재하지 않는다. Dalberg Global Development Advisor(2014) 역시 혁신적 재원 조달(innovative financing)에 관한 합 의된 정의는 존재하지 않으나, '혁신적’이란 개념은 공통적으로 재원 동원(resource mobilisation), 비전통적 ODA(non-traditional ODA), 개발영향(development impact)을 특징으로 한다고 설 명하고 있다. 여러 양 - 다자 공여기관 및 개발은행들은 2000년대 후반에 이르러 혁신적 개발재 원 조달의 논의가 활발해지자 해당 개념에 대한 정의를 제시하였는데, 여기에서도 '혁신적'이라는 개념에 역시 공통적인 요소들을 찾아볼 볼 수 있다.

먼저, 세계은행(2009)은 혁신적 개발 재원(innovative finance)의 정의를 사업 분야와 재원출 처로 분류하여 기업참여 민간협력(공공부문의 민간재원), 순수민간투자(민간부문의 민간재원), 연 대형 메커니즘(공공부문의 정부재원), 촉매적 메커니즘(민간부문의 공공재원) 등으로 제시한 바 있다. 이어, 2013년에 발간한 보고서에서는 재원 출처나 사업 분야를 넘어서 특징 중심으로 분류 하였는데, 이는 다음과 같다. 첫째, 새로운 재원 소스를 이용하거나 혹은 새로운 파트너가 참여함 으로써 추가적(additional)인 개발 자금을 생성하는 것; 둘째, 특히 긴급한 필요 및 위기 상황에 대비하여 전달 시간 및 비용을 감소시킴으로써 금융흐름의 효율성(more efficient)을 향상하는 것; 셋째, 금융 흐름을 자금 흐름과 현장의 측정가능한 성과를 명확하게 연계함으로써 보다 성과 지향적(results-oriented)으로 만드는 것이라고 설명함으로써 '혁신적'의 의미를 구체화하고 확장 시켰다.

앞서 논의 흐름에서 언급한 바와 같이, UN(2011)에서는 혁신적 개발재원의 조달이 효과적이 기 위해서는 관련 메커니즘은 안정적이고 예측 가능한 자원을 동원해야하며, 전통적 재원의 대체 제가 아닌 보완재의 성격을 가지고, 개발도상국의 우선 순위와 관련하여 지출되어야 한다고 말하 고 있다. 이는 혁신적 개발재원 뿐만 아니라, 모든 개발재원에 적용되는 내용으로써 UN은 혁신 적의 개념을 개발재원으로써의 기본적 요구에 충실하되 보완재의 역할을 할 수 있는 것으로 보고 있는 것을 알 수 있다. 한편, 혁신적 개발재원의 주요 특징으로는 첫째, 공적 재원 및 협력이 민 간 재원 조달에 있어 촉매제의 역할을 하는 경우, 둘째, 개발도상국의 재원을 송금하는 국가 간의 국제 협력일 경우, 셋째, 새로운 방식을 통해 추가적인 개발재원을 창출해내는 것 등을 제시하고 있다. 
유엔개발계획(UNDP)에서는 이와 같은 특징을 반영하여 혁신적 개발재원 카테고리를 4가지로 제시하였는데, 이는 다음 그림 1 과 같다. 첫째, 국제화된 활동에 대한 글로벌 수준의 세금, 회비 혹은 의무적 부담금으로 자금을 레버리지하거나 행동에 변화를 주기 위한 목적을 가지고 있다. 대표적인 예로 금융거래세, 탄소세, 항공세 등이 있다. 둘째는, 자발적인 연대 기여금으로써 해당 카테고리 역시 새로운 재원을 창출해내는 유형이다.

〈그림 1〉 혁신적 개발재원의 4 가지 카테고리

\begin{tabular}{|c|c|c|c|}
\hline Category & Purpose & Examples & \multirow{3}{*}{$\begin{array}{l}\text { Designed and agreed by } \\
\text { international treaties or } \\
\text { commercial actors }\end{array}$} \\
\hline $\begin{array}{l}\text { Taxes, dues or } \\
\text { mandatory charges } \\
\text { globally }\end{array}$ & $\begin{array}{l}\text { Leverage funds and } \\
\text { influence behaviour }\end{array}$ & $\begin{array}{l}\text { - } \text { Carbon tax } \\
\text { - } \text { Tobin tax } \\
\text { - Airfare } \operatorname{tax}\end{array}$ & \\
\hline $\begin{array}{l}\text { Voluntary solidarity } \\
\text { contributions }\end{array}$ & Leverage funds & $\begin{array}{l}\text { RED products } \\
\text { Global Digital } \\
\text { Solidarity Fund }\end{array}$ & \\
\hline $\begin{array}{l}\text { Front-loading and debt- } \\
\text { based instruments }\end{array}$ & $\begin{array}{l}\text { Address short-term } \\
\text { capital needs }\end{array}$ & $\begin{array}{l}\text { - IFFIm } \\
\text { - } \quad \text { Green bonds } \\
\text { - }\end{array}$ & \multirow{2}{*}{$\begin{array}{l}\text { Designed and managed by } \\
\text { development agencies, } \\
\text { often in pratnership with } \\
\text { other agencies and through } \\
\text { public-private partnerships }\end{array}$} \\
\hline $\begin{array}{l}\text { Market-based } \\
\text { mechanisms }\end{array}$ & $\begin{array}{l}\text { Leverage funding and } \\
\text { target funding for } \\
\text { better results }\end{array}$ & $\begin{array}{l}\text { - Risk insurance } \\
\text { Advance-market } \\
\text { commitments }\end{array}$ & \\
\hline
\end{tabular}

출처: Devfin (2014), Innovative finance gap analysis

셋째, 전기이행(front-loading) 및 채무기반수단(debt-based instruments)은 단기 자본 수 요 대응을 위해 초기 시점에 공적 자금을 투입함으로써 개발재원이 효율적으로 활용될 수 있게 하는 목적으로 대표적인 것이 국제백신금융기금(IFFIm), 녹색채권 등이 예시이다. 마지막으로는, 시장기반 메커니즘(market-based mechanism)으로 이들은 공적자원을 통해 민간재원을 레버리 지하고 더 나은 개발 영향을 이끌어내려는 것을 특징으로 한다. 마지막 카테고리의 수단은 최근 많은 관심을 끌고 있는 보증 등이 있다. 한편, 동 개념의 카테고리를 설명하면서 개발을 위한 재 원의 혁신적 출처(innovative sources of finance for development)와 자원을 전달하는 데 있 어서의 혁신적 방법(innovations in the ways resources are delivered)의 차별성을 인지하는 것은 중요하다고 또한 여기서 밝히고 있다.

$\mathrm{OECD}(2009)$ 에서는 혁신적 개발재원을 “공공 또는 민간 부문에 의한 기존의 전통적인 접근법 과는 달리 개발 목적의 자금 조달 수단과 개발을 촉진하기 위한 활동의 결합된 메커니즘”이라고 
정의하고 있다. 이를 세 가지 유형으로 제시하는 데 첫째, 민간 및 공적 자금을 모이기 위한 새로 운 접근방식(new approach)으로 파트너국가의 혜택을 위한 활동을 규모화하거나 발전하는 것이 며, 둘째, 새로운 수익원(new revenue stream)으로 다년간 개발활동에 지정된 새로운 조세, 채 권 발행, 자발적 기여금 등이며, 셋째는 새로운 인센티브(new incentive)로써 진행 중인 개발활 동을 규모화하거나 시장 실패를 해결하기 위한 금융 보증, 사회적 책임 혹은 보상 등을 의미한다.

리딩그룹(leading group)은 혁신적 개발재원 조달을 전통적 원조 흐름에 의해서는 해결되지 않고 남아있는 도전과제들에 대한 금융 솔루션이라고 정의한다. 이러한 재원 조달에는 두 개의 하위 카테고리들이 존재하는 데 첫째는 혁신적 자원(innovative sources)로서 여러 경제 섹터로 부터 오는 지속가능개발을 위한 새로운 금융 흐름 생성을 돕는다. 다음으로는 혁신적 메커니즘 (innovative mechanism)으로서 기존 자원의 효율성, 영향 및 레버리지를 극대화하는 것을 돕는다.

한편, 2014년 1월 나이지리아에서 열린 리딩그룹의 최근 연간총회세션에서는 Post-2015 시 대에서 혁신적 개발재원 관련 이니셔티브들에 의한 동원 금액을 추적하기 위해서는 '개발을 위한 혁신적 개발재원 조달(innovative financing for development)'의 공통된 정의가 필요하다는 것 에 합의가 이루어졌다. 이러한 합의는 2014년 6월 파리에서 '2015년을 위한 준비: 지속가능개발 과 기후변화에 있어 혁신적 파이낸싱의 역할(Preparing for 2015: The Role of Innovative Financing in Sustainable Development and Climate Change)'을 주제로 열린 리딩그룹의 전 문가 워크숍에서 역시 강조된 바 있다.

이렇듯 개념의 정의에 대한 수요가 높아지는 가운데 동 개념에서 가장 핵심적인 것은 '혁신적' 을 어떻게 정의내릴 수 있을 것인가에 대한 것이다. 다음 장에서는 혁신적 개발재원 조달의 개념 이 발전해온 과정과 그 가운데에서 '혁신적인 성격'이 보여주는 주요 특징에 대해 알아봄으로써 혁신적 개발재원 조달 개념에 대해 파악해보도록 한다.

\section{2. 혁신적 개발재원 조달 개념의 발전}

혁신적 개발재원 조달은 발전하는 개념이다. 앞 장에서 언급한 것처럼 국제적으로 공통된 정의 는 존재하지 않는다. 2001년 이후 혁신적 개발재원의 조달은 매년 $11 \%$ 의 성장을 기록했는데, 이 는 2001년 약 20억 달러 규모에서 시작하여 2012년 거의 90억 달러까지 성장한 수준이다. 이는 혁신적 개발재원 조달 분야에서 기존 수단의 성장보다는 새로운 수단이 출현하고 있음을 반영하 는 것이다. 구체적으로는 자발적 탄소시장과 같은 마이크로파이낸스 펀드(microfinance fund), 테마펀드(theme fund), 옥션(auction) 등이 성장의 대부분을 주도해왔다. 
초기에 개발협력에서의 혁신적 재원 조달은 $\mathrm{ODA}$ 에 더하여 추가적인 자금을 끌어오는 수단과 관련한 것이 대부분이었다. 그러나 최근에는 서로 다른 기술을 보유한 새로운 행위자의 참여 또 는 다양한 시장기반 메커니즘을 활용함으로써 보다 효과적인 개발 원조를 제공하는 다양한 방법 들 즉 '보다 스마트한 원조(smarter aid)'를 의미하는 것으로 확장되어 왔다. 이는 혁신적 개발재 원 조달이 자금을 동원하는 것에 그치지 않고 그들을 배분 혹은 배치하는 새로운 방식까지도 포 함하고 있음을 의미한다.

Global Development Incubator(2014) 보고서에서는 역시 혁신적인 성격으로 두 가지 측면을 들었다. 첫째는 기존의 흐름을 보완하는 자본 원천으로써의 혁신적 개발재원 조달을 의미한다. 이 는 공여국가들로부터 안정적이고, 예측가능하며, $\mathrm{ODA}$ 를 보완하는 성격의 자원을 제공하는 것을 말한다. 두 번째 측면은 자본의 배치(활용)로의 혁신을 의미한다. 이는 혁신적인 메커니즘이 위험

제 I 장

\section{개}

발

협

력

이

슈

제 II 장

제 III 장 을 재분배하고, 유동성을 증가시키며, 프로젝트 수요와 투자 기간을 매칭함으로써 개발이니셔티 브를 보다 효과적이고 효율적으로 만들 수 있다는 데 기인한다. 따라서 개발을 위한 혁신적인 재 원 개념 정의의 가장 두드러진 특징은 자원의 동원에 대한 접근방식과 글로벌 개발 도전과제를 해결하기 위해 금융흐름의 효과성 및 효율성 증진 모두를 의미한다는 것이다.

이로 인해 혁신적 개발재원 마련에 활용되는 금융 수단(financial instruments) 역시 기본적 인 자원 동원 목적의 수단으로부터 다양한 범위의 문제해결 중심 수단으로의 변화를 보여주고 있 다. 2000년대 초반에 활용한 채권 및 보증 수단은 주로 국제금융기관의 자원 동원에만 초점을 두 었다. 상업적 투자를 독려하기 위해 공적기관들은 현재 자금을 제공하는 대신 미래에 대출 상환 을 약속하거나 성공하지 않은 프로젝트의 위험을 감수해주었다. 그러나, 최근에는 민간부문이 개 발로부터의 위험을 분산하고 보상받는 것을 통한 수단이 보다 많은 견인력을 얻게 되었다. 즉, 처 음에는 채권 혹은 보증을 활용한 단순 재원 레버리지에 초점을 맞추었다면, 최근에는 민간이 위 험과 보상을 공유하면서 개발효과 달성을 이끌어내는 것이 강조되고 있으며, 지분투자(마이크로펀 드, 투자펀드) 혹은 성과기반의 재원조달(result-based financing) 등을 그 예로 들 수 있다. 과 거 개발협력의 재원이 대부분 증여(grant)형태의 원조에 의존했다는 것을 감안하면, 이는 매우 중요한 패러다임의 전환이라 할 수 있다.

또한 재원이 조달되는 섹터의 구성에서 역시 시대에 따라 변화를 가져왔다. 2000년 이후, 혁 신적 개발재원 조달 메커니즘은 에너지, 환경 분야에서 가장 많은 자원을 동원하였으며, 그 다음 으로는 금융접근성, 글로벌 보건 분야가 차지하였다. 그러나 최근에는 그동안 재원 조달에 있어서 는 상대적으로 제한된 분야였던 농업, 교육, 물 분야까지 혁신적 개발재원 조달을 위한 노력이 확 장되고 있는 추세이다. 
시장기반메커니즘(market-based mechanism)은 위험을 조정하는 수익을 목표로 하는 메커니 즘으로 2001년 이후 성장해왔다. 시장수익이하를 목표로 하는 메커니즘이 전체 지형의 절반 이상 (2012년 기준 53\%)을 차지하고 있지만, 최근 사회 및 금융 수익 모두를 생각하는 기회에 초점이 맞추어지고 있다. 이러한 동향에는 두 가지 측면이 있다. 첫 번째 측면은 투자자의 관점에서 위험 조정시장수익을 제공하는 투자의 출현이다. 이는 개발은행 대차대조표에 의해 지원받는 녹색채권, 마이크로 파이낸스 펀드 및 임팩트투자펀드와 같은 저위험투자를 포함한다. 두 번째 측면은 실행 자의 관점에서 민간기업 및 $\mathrm{NGO}$ 가 사회재를 제공하기 위해 경쟁하는 성과기반 파이낸싱 기회의 출현이다.

또한 $\mathrm{ODA}$ 와의 관계에 있어서 역시 혁신적 개발재원의 역할은 발전해왔다. 초기에는 혁신적 개발재원이 $\mathrm{ODA}$ 에 보완적 성격을 가져야 하며, 예측 가능하고 안정적이어야 함을 강조해왔다. 보완적의 의미는 선진국이 약속한 ODA 규모인 GNI 대비 $0.7 \%$ 와 별개로 재원을 조성해야 한다 는 측면이 강했다. 그러나 최근에는 $\mathrm{ODA}$ 를 촉매제로 삼아 재원을 동원해야 하는 방향이 강조됨 에 따라 재원의 규모와 사용 모두에 있어 혁신적 개발재원과 ODA간의 긴밀한 관계가 형성되어 있음을 알 수 있다.

〈표 2〉 혁신적 개발재원 조달 개념의 발전

\begin{tabular}{|c|c|c|c|}
\hline & 혁신적 개발재원 논의 초기 & & 혁신적 개발재원 논의 최신 동향 \\
\hline 성격 & 추가적인(additional) & $\Rightarrow$ & 보다 효과적인(effective), 현명한(smarter) \\
\hline 자금용도 & 자금 조달 (sourcing) & $\Rightarrow$ & 자금 조달 및 배치(deployment) \\
\hline $\begin{array}{l}\text { 금융수단의 } \\
\text { 활용 }\end{array}$ & $\begin{array}{c}\text { 재무 레버지리지 목적의 } \\
\text { 채권, 보증 }\end{array}$ & $\Rightarrow$ & $\begin{array}{c}\text { 위험분담 및 개발문제 해결 목적의 지분투자, } \\
\text { 성과기반파이낸싱 }\end{array}$ \\
\hline 시장 메커니즘 & 시장이율 이하 수익기대 & $\Rightarrow$ & 일정 수준 이상의 재무적 수익 + 긍정적 개발 영향 \\
\hline 사업 유형 & 원조중심 시범사업 & $\Rightarrow$ & 민간자본 유치 목적의 성과기반 파이낸싱 \\
\hline 섹터 & 보건, 환경, 인프라 중심 & $\Rightarrow$ & $\begin{array}{c}\text { 농업, 에너지, 인프라, } \\
\text { 이머징마켓 내 소비자, 기업 투자 }\end{array}$ \\
\hline 메커니즘 & 세금, 자발적 민간기여금 & $\Rightarrow$ & $\begin{array}{c}\text { 해외투자펀드, PPP, 위험분산, } \\
\text { 민간기업 및 지역투자 동원 목적의 인센티브 }\end{array}$ \\
\hline $\mathrm{ODA}$ 와의 관계 & $\mathrm{ODA}$ 재원과 별개로 보완적 성격 & $\Rightarrow$ & ODA 재원을 촉매제로 활용하여 동원 \\
\hline
\end{tabular}

출처: 저자 작성

위의 〈표 2〉는 지금까지 언급한 혁신적 개발재원 조달 개념에 대한 발전 과정들을 정리해보았 다. 이를 통해 '혁신적'의 성격은 길지 않은 시간임에도 불구하고 약 10 여년의 시간 동안 빠르게 변화해왔으며 확장되어 왔다는 것을 알 수 있다. 사실 아래 표에서 표현하고 있지는 못하지만, 같 
은 시대 선상에서도 일부 이해관계자들에 의해 '혁신적'이라고 명명된 이니셔티브들은 다른 이해 관계자들에게는 혁신적이라고 생각되지 않을 수도 있을 것이다. 예를 들어, 최근 원조기관에서 새 로운 혁신적 개발재원 조달 메커니즘으로 주목받는 채권과 보증 등의 금융수단은 이미 다자개발 은행 혹은 개발금융기관에서는 오래전부터 활용되어온 수단이었다. 이는 혁신적 재원달이 금융적 혁신을 의미하는 것은 아니며, 기존 수단을 활용하여 개발재원 동원과 해결방안을 혁신적으로 제 시하는 것을 의미한다. 따라서 개념의 발전에 대해서 시간의 흐름대로만 명확히 구분하는 것은 한계가 있겠지만, 전체적으로 혁신적 개발재원 조달의 개념은 재원의 조달 자체 외에도 재원 조 달 활동으로 인해 지속가능 개발에 최대한 긍정적 영향을 가져오는 방향으로 진화되어가고 있다 는 것이다.

\section{IV. 혁신적 개발재원 조달의 최신 동향}

혁신적 개발재원 조달의 개념이 발전해온 것과 마찬가지로 해당 메커니즘과 사업 모델 역시 발 전해오고 있다. 최근 $\operatorname{Dalberg}(2014)$ 는 이러한 특징을 반영하여 혁신적 개발재원 조달 메커니즘 을 집합(aggregation) - 혼합(blending) - 조정(coordination)의 영문단어 앞글자를 참고하여 $\mathrm{ABC}$ 모델로 분류 정리하였으며, 각 특징이 갖는 주요 의미는 다음 〈그림 2〉와 같다.

〈그림 2〉 혁신적 개발재원의 주요 특징

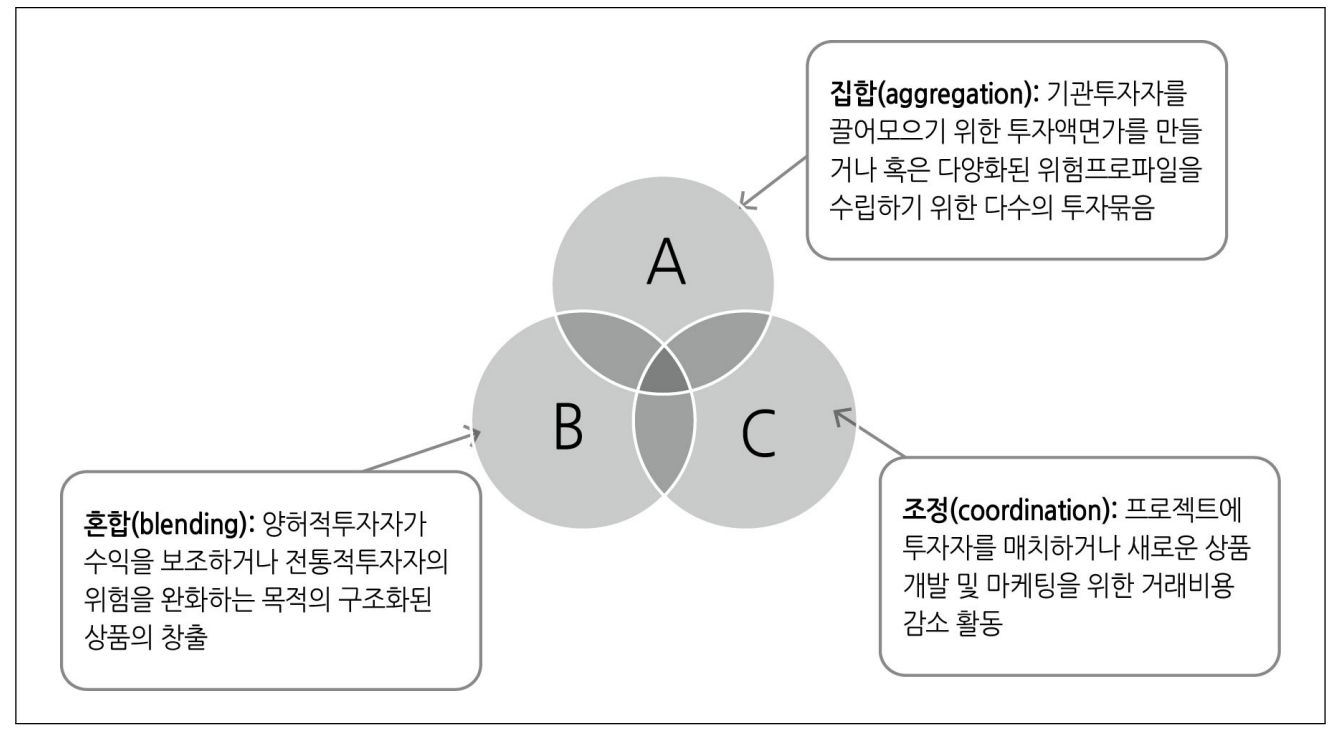

출처: Dalberg (2014) 
혁신적 개발재원 조달은 전통적 금융 접근방식 대비 몇 가지의 혜택을 가지고 있다. 예를 들 면, 이러한 메커니즘이 존재하지 않았다면 사회투자에 참여하지 않을 만한 상당한 규모의 민간부 문 자본을 개발문제 해결을 위해 배치한다. 인프라와 같은 공공재에 투자를 가능하게 하는 보증 과 임팩트투자펀드는 자본 접근성에 있어 고군분투할 중소기업들을 지원하는 것들을 그 사례로 들 수 있다. 뿐만 아니라 이는 금융자산의 구조화 및 중개를 통해 위험을 배분하고, 유동성을 강 화하고, 변동성을 감소시키며, 투자시점의 불일치를 피하게 함으로써 개발프로그램의 수요를 충 족할 수 있도록 전환한다.

혁신적 개발재원 조달 메커니즘은 투자를 원하는 개인과 기관의 자금 조달을 통해 재원을 필요 로 하는 프로젝트에 신속히 공급하며 이는 전통적 공여기관 및 자선재단이 제공하는 재원보다 대 규모일 수 있다. 예를 들어, 녹색채권(green bonds)이나 테마채권(theme bonds)은 윈드팜, 지 속가능산림관리 및 도시인프라와 같이 저탄소인프라 투자를 지원하기 위한 자본을 제공한다. 추 가적으로, 보건담보보증(the pledge guarantee for health)은 자원이 약정되고 지출되는 사이의 갭기간 동안 프로젝트와 기관을 위한 재원 조달을 연결해주는 역할을 한다. 또한, 혁신적 협력방 식은 전통적 개발협력 방식에 비해 규모가 매우 작고, 진정한 혁신성을 보여주는 사례는 그 중에 서도 소수인 상황이다. 그럼에도 불구하고, 동 시장에 참여하고자 하는 기관들이 다양해지고 있어 자본 스펙트럼이 심화되고 있으며, 중개기관을 설립하여 거래비용을 낮추고자 하는 등 시장형성 확대를 위한 노력들이 지속되고 있다.

또한, 이러한 메커니즘의 '혁신성'을 인정받기 위해서는 해당 재원이 새로운 상품(new product), 새로운 시장(new market), 혹은 새로운 참여자(new participants)등을 포함하여 가치를 창출하 고 있는지 역시 입증할 필요가 있다. 이를 입증하기 위한 채널의 세 가지 유형으로는 자원 동원, 금융 중개, 자원전달을 들 수 있는데, 먼저, 자원 동원(resource mobilisation)은 부정적 외부화 효과를 캡쳐(피구세5))하는 의무적 메커니즘. 자발적 메커니즘(복권), 상업과 자선적 목적을 결합 하는 메커니즘(red)을 포함한다. 금융 중개(financial intermediation) 측면에서 혁신적 파이낸싱 은 많은 이해관계자 간의 위험 분산, 유동성강화, 자원 통합을 통해 효율성을 창조한다. 중개 기 능은 거래비용 감소를 위한 기관 역량 개발(소규모 투자 기회 통합) 및 금융 및 이행 위험 감소 (투자보험 증진)를 포함한다. 자원 전달(resource delivery)은 개발프로그램을 위한 투자의 일부 혹은 직접적 펀딩으로써 자원의 할당 혹은 지출을 의미한다. 이는 투명성 수준의 향상, 인센티브

5) 외부불경제가 발생하였을 때 정부가 개입하여 경제주체에게 세금으로 비용을 부담하게 함으로써 불경제를 완화시키는 조 세 정책이다. $\mathrm{A}$ 가 어떤 행위를 가하였을 때 특정한 의도를 가지든 가지지 않든 $\mathrm{B}$ 는 긍정적 혹은 부정적인 영향을 받게 되는데 이를 '외부효과(externalities)' 또는 '외부성'이라고 한다. 본래 $A$ 는 이 외부효과에 대한 비용이나 보상을 지불할 의 무를 가지고 있지 않지만, 외부효과의 결과가 심각하여 외부불경제가 발생하면 정부가 $A$ 에게 피구세를 부담하게 하여 문 제를 어느 정도 해소한다. [네이버 지식백과] 피구세 [pigouvian tax, 一稅] (시사상식사전, 박문각) 
창출 및 일치(성과기반지불계약) 및 다른 행위자들의 활동 조정 등 보다 효과적인 자원의 배치를 지원하는 이니셔티브를 포함한다(〈표 3〉, 〈그림 3〉 참조).

〈표 3〉혁신적 개발재원 조달 메커니즘 유형

\begin{tabular}{|c|c|c|}
\hline \multirow{6}{*}{$\begin{array}{l}\text { 증권 및 } \\
\text { 파생상품 } \\
\text { Securities and } \\
\text { Derivatives }\end{array}$} & $\begin{array}{l}\text { 채권 } \\
\text { Bonds and Notes }\end{array}$ & $\begin{array}{l}\text { 미소금융 혹은 기후변화 방지와 같은 개발 목적을 위해 } \\
\text { 자본시장에서 모집된 채무 파이낸싱 }\end{array}$ \\
\hline & $\begin{array}{l}\text { 보증 } \\
\text { Guarantees }\end{array}$ & $\begin{array}{l}\text { 금융손실이 발생한 경우 지급제공하는 금융 약정으로 보험상품을 } \\
\text { 포함하며 다른 자금제공자를 끌어들이기 위한 위험완화 } \\
\text { 인센티브로 작용함. }\end{array}$ \\
\hline & $\begin{array}{l}\text { 대출 } \\
\text { Loans }\end{array}$ & $\begin{array}{l}\text { 녹색크레디트라인과 같이 특정 개발 사업을 시행하기 위해 } \\
\text { 차입자에게 양허적 상환 조건으로 자금을 융자 }\end{array}$ \\
\hline & $\begin{array}{l}\text { 미소금융투자펀드 } \\
\text { Microfinance Investment } \\
\text { Funds }\end{array}$ & $\begin{array}{l}\text { 저소득층 차입자에게 자금을 제공하는 개도국 마이크로크레딧 } \\
\text { 대출자에게 자금을 지원하는 투자펀드 }\end{array}$ \\
\hline & $\begin{array}{l}\text { 기타투자펀드 } \\
\text { Other Investment Funds }\end{array}$ & $\begin{array}{l}\text { 서로 다른 위험/수익 프로파일을 가진 투자자를 혼합하여 특정 } \\
\text { 개발 도전과제를 대상으로 자금을 모으고 구조화하는 투자기금 }\end{array}$ \\
\hline & $\begin{array}{l}\text { 기타 파생상품 } \\
\text { Other Derivative Products }\end{array}$ & $\begin{array}{l}\text { 주택대출 혹은 기상이벤트와 연동하는 증권과 같이 다른 자산의 } \\
\text { 성과로부터 가치를 파생하는 금융수단 }\end{array}$ \\
\hline \multirow{5}{*}{$\begin{array}{l}\text { 성과 기반 } \\
\text { 메커니즘 } \\
\text { Results-, } \\
\text { output-, } \\
\text { performance- } \\
\text { based } \\
\text { mechanisms }\end{array}$} & $\begin{array}{l}\text { 선행시장약정 } \\
\text { Advanced market } \\
\text { commitments }\end{array}$ & 상품이 개발되는 즉시 가격/시장을 보장하는 자금 약정 \\
\hline & $\begin{array}{l}\text { 보상 및 상금 } \\
\text { Awards and Prizes }\end{array}$ & 경쟁적 선정과정에서 개발해결책을 위한 금융보상 \\
\hline & $\begin{array}{l}\text { 개발영향채권 } \\
\text { Development Impact Bonds }\end{array}$ & $\begin{array}{l}\text { 개발사업에 먼저 투자하고 정부/공여기관이 달성 성과에 } \\
\text { 기반하여 이자와 함께 투자를 상환 }\end{array}$ \\
\hline & $\begin{array}{l}\text { 성과기반계약 } \\
\text { Performance-based } \\
\text { contracts }\end{array}$ & $\begin{array}{l}\text { 구체적인 성과 타겟을 충족한다는 조건에서 지출하는 증여 계약 } \\
\text { 구조 }\end{array}$ \\
\hline & $\begin{array}{l}\text { 채무스왑 및 바이다운 } \\
\text { Debt-swaps and } \\
\text { buy-downs }\end{array}$ & $\begin{array}{l}\text { 개발목표 달성에 기반하여 개도국 채무상환 의무가 전가되거나 } \\
\text { 감소됨 }\end{array}$ \\
\hline \multirow{2}{*}{$\begin{array}{l}\text { 자발적 기여 } \\
\text { Voluntary } \\
\text { contributions }\end{array}$} & $\begin{array}{l}\text { 탄소 옥션 } \\
\text { Carbon Auctions }\end{array}$ & $\begin{array}{l}\text { 탄소 신용 거래 및 배출 감소를 위해 법적으로 구속된 교환에 } \\
\text { 있어 자발적 참여 }\end{array}$ \\
\hline & $\begin{array}{l}\text { 소비자 구매액 일부 기부 } \\
\text { Donations as part of } \\
\text { consumer purchases }\end{array}$ & $\begin{array}{l}\text { 소비자 상품 구매액의 일부가 지정된 개발도전과제를 위한 } \\
\text { 자금으로 기부됨 }\end{array}$ \\
\hline $\begin{array}{l}\text { 강제 부과 } \\
\text { Compulsory } \\
\text { charges }\end{array}$ & $\begin{array}{l}\text { 세금 } \\
\text { Taxes }\end{array}$ & $\begin{array}{l}\text { 특정 개발도전과제를 위한 자금 모집을 위해 정부에 의해 부과된 } \\
\text { 특정 세금 }\end{array}$ \\
\hline
\end{tabular}

출처: Dalberg (2014) 
〈그림 3〉혁신적 개발재원 조달 메커니즘의 유형별 사례

\begin{tabular}{|c|c|c|c|c|c|c|}
\hline & \multicolumn{3}{|c|}{ 무엇이 ‘혁신적’으로 만드는가? } & \multicolumn{3}{|c|}{ 개발문제를 어떻게 지원하는가? } \\
\hline & 새로운 상품 & 새로운 시장 & $\begin{array}{l}\text { 새로운 } \\
\text { 참여자 }\end{array}$ & 자원동원 & 금융중개 & 자원전달 \\
\hline \multicolumn{7}{|l|}{ 증권 및 파생상품 } \\
\hline 테마채권 & & & 0 & 0 & 0 & \\
\hline 보증 & & 0 & 0 & & 0 & \\
\hline 테마융자 & 0 & & & 0 & & \\
\hline 미소금융투자펀드 & & 0 & 0 & & 0 & \\
\hline 기타 투자펀드 & & 0 & & 0 & 0 & \\
\hline 기타 파생상품 & 0 & 0 & & 0 & 0 & \\
\hline \multicolumn{7}{|l|}{ 성과기반 파이낸싱 } \\
\hline AMC & 0 & 0 & & 0 & & \\
\hline 보상 및 상금 & 0 & & & 0 & & \\
\hline 개발영향채권(DIB) & 0 & & & & & 0 \\
\hline 성과기반계약 & & & 0 & & & 0 \\
\hline 채무스왑 및 buy-down & 0 & & & 0 & & \\
\hline \multicolumn{7}{|l|}{ 자발적 기여금 } \\
\hline 탄소옥션(자발적) & 0 & 0 & 0 & 0 & & \\
\hline 소비자 구매 & & & 0 & 0 & & \\
\hline \multicolumn{7}{|l|}{ 강제 부과 } \\
\hline 세금 & 0 & & & 0 & & \\
\hline
\end{tabular}

출처: Dalberg (2014) 참조

일부 사업 모델은 이미 성공여부를 입증하였으며, 어떤 것들은 규모화의 시점에 다다랐으며, 새로운 아이디어를 시험하는 단계에 있는 모델들도 있다. 보증과 채권과 같이 입증된 모델은 구 조를 반복하거나 규모화 할 수 있는 단계에 이미 도달하였으며, 위험을 평가하고 지불 조건을 결 정하기 위한 명확한 표준 역시 수립된 상황이다. 반면, 규모화 시점에 있는 모델들은 주로 성과 기반의 계약들로서 사업을 수립하는 것은 가능하나 성숙 단계에 이르기 위한 충분한 성과데이터 가 없는 것이 제약 상황이다. 마지막으로, $\mathrm{AMC}$ 와 개발영향채권(Development Impact Bond, $\mathrm{DIB}$ ) 등은 여전히 개발 단계에 있으며 그들이 민간자본을 끌어들이고 시범단계를 넘어 규모화하 기까지 양허적 공여자들로부터 상당한 지원을 요구한다.

앞으로 상당한 자본 비용을 요구하고 전통적으로 공적 부문 영역에서 있던 사업운영을 규모화 하기 위해서는 협력적 공공-민간부문 접근방식을 활용해야 한다. 보건, 금융서비스, 농업과 같은 많은 섹터들에서 새로운 상품을 기획, 생산, 마케팅 및 배분에 있어 전문성을 갖춘 민간 기업은 사회변화를 일으키는데 매우 중요한 역할을 할 것이다. 혁신적 개발재원 조달 메커니즘은 민간 기업이 새로운 상품을 창조하고 신시장에 진입하는 데 필요한 투자를 만드는 것을 독려하는 인센 티브를 조정할 수 있다. 예를 들어, GAVI가 지원하는 $\mathrm{AMC}$ 는 개도국 내 폐렴백신을 위한 수요 위험을 재할당하여 제약회사가 보다 많은 백신을 대규모로 낮은 비용에 생산할 수 있도록 하였다. 


\section{〈상자 2〉혁신적 개발재원 조달 사례}

\section{사례. 미국 USAID의 Development Credit Authority (DCA) 프로그램: ‘보증을 활용한 민간재원 동원 미 빈곤층 금융접근성 향상}

USAID는 지속가능한 개발 영향 노력의 주요 일환으로 파이낸싱(financing)에 중점을 두고 있으며, Development Credit Authority (이하 DCA) 프로그램은 보증(guarantee)라는 금융 수단을 통하여 이러한 USAID의 노력을 지원하는 프로그램이다. DCA 프로그램은 신용보증 및 직접 융자, 기술지원, 현지사무소 자문 제공 등을 도구로 활용하는 혁신 적 수단으로써 위험 분산(risk sharing) 메커니즘을 활용하여 지역 상업 은행들의 자금을 개도국 빈곤층 금융접근성 향상에 사용할 수 있도록 하며, 1999년 사업 시작 이래 총 480개의 보증 계약을 통해 42억 달러 규모의 민간자본 동원 성과를 이끌어냈다. 이는 23배의 레버지리(leverage) 효과를 가져왔다.

\section{ㅁ DCA 프로그램의 3가지 구성요소}

1. 신용 보증 및 직접 대출(credit guarantees and direct loans): DCA는 금융기관이 개발에 중요한 분야 혹은 부분 에 대출을 제공하는 것을 독려하기 위해 대출 위험(lending risk)의 일부분을 분담한다.

2. 기술 지원(technical assistance): DCA는 차입자의 신용도 수립, 대출자의 자발적 신용한도 연장 증진, 차입자와 대출자 간의 연계를 만들기 위한 기술지원을 제공을 위해 현지사무소와 협력한다. 기술지원의 유형으로는 (1) 잠재 적 차입자에게 현금흐름 예측 및 기본 문서 작성을 익히는 것을 돕는 것, (2) 은행이 대상 섹터에 특정한 대출 상 품과 마케팅 전략을 개발할 수 있도록 지원, (3) 잠재적 차입자와 은행을 연결, (4) 보증을 사용하는 대출 관리자 교육 등이 있다.

3. 현지사무소 대상 자문서비스 제공 (advisory services to missions): DCA는 USAID 현지사무소를 대상으로 상업 대출에 대한 차입자의 접근성 기회를 최대화하기 위한 방법으로 어떻게 분야별 전략을 기획할 것인지에 대해 자문 을 제공한다.

\section{ㅁ DCA 프로그램의 운영방식}

먼저 대상 목표 섹터에서 차입자에게 대출해주기 위해 1천만 불의 은행 자금을 동원하는 목표를 달성하기 위해서는 국가위험, 대부자위험, 차입자위험, 거래위험 등을 근거로 차입자에 의해 상환되지 않을 금액의 $50 \%$ 를 예측한다. 예 를 들어, 동 금액이 1.025 백만 달러로 측정되었다면, USAID는 미국 재무부를 통해 USAID가 상환받지 못할 것으로 예측되는 금액을 보조받는다 (예. 1 백만 달러). 그리고 나머지 25,000달러는 은행수수료로 충당하게 된다.

\section{〈그림 4〉 DCA의 운영방식}

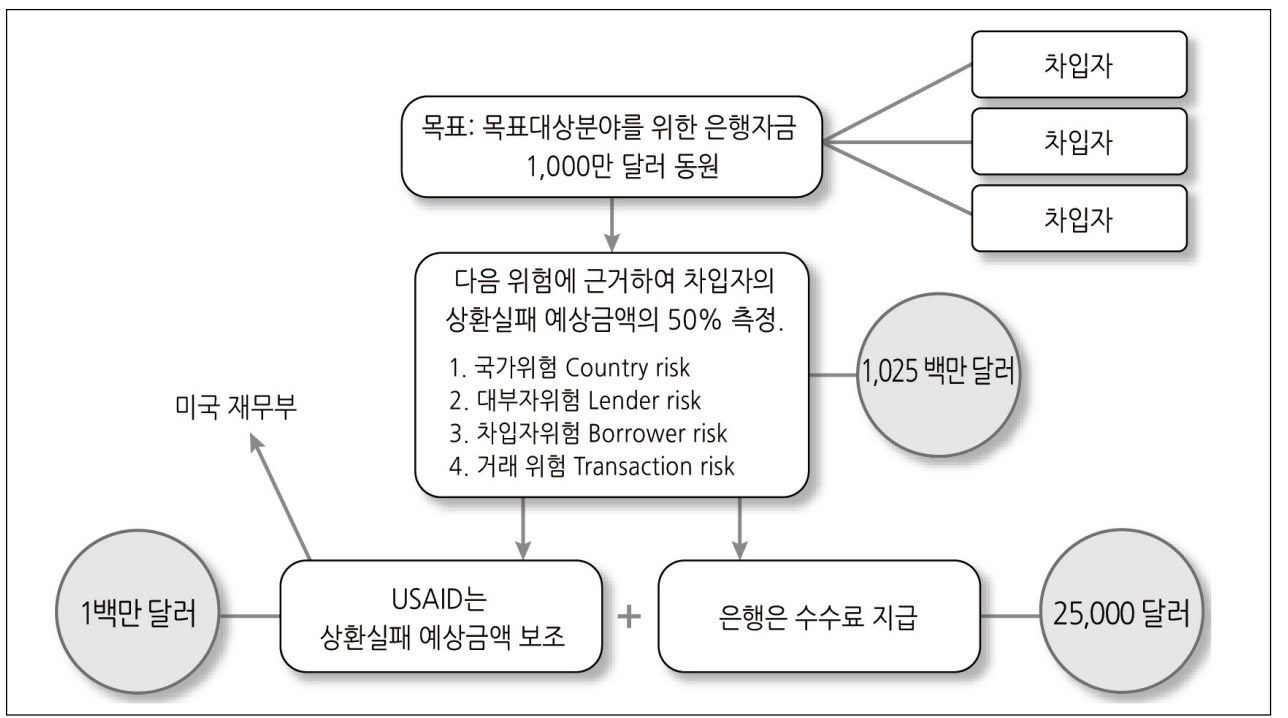

출처: USAID 발표자료 (2016.02.09) 


\section{ㅁ DCA 프로그램의 혁신적 성과: 추가성과 개발영향}

$\mathrm{DCA}$ 는 다른 금융기관과는 다르게 차입자에게 직접 돈을 빌려주지는 않으나, 그들의 대출 조건, 대출 유형, 대출 유형 내 투자 등을 포함하여 민간대출자의 장단기 의사결정, 자본 할당에 영향을 준다. 보증추가성은 이러한 보증 없이는 가능하지 않았던 것이 DCA 보증을 통해 성취된 추가적인 대출을 의미한다. 차입자 영향은 중요한 영향으로 DCA 보 증의 궁극적 목표이다. DCA 보증으로부터의 차입자 영향은 일반적으로 차입자가 DCA가 보증하는 대출에 접근하는 성과를 의미하며, 차입자들이 받지 못하거나 더 나은 조건으로는 받을 수 없는 대출을 의미한다.

출처: USAID 발표자료 (2016.02.09)

\section{V. 결론 및 시사점}

개발재원 조달의 중요성이 강조됨에 따라 다양한 개념, 메커니즘, 수단 및 사업 사례들이 등장 하게 되었고 이는 개발재원 조달의 영역이 복잡해지고 있음을 나타내고 있다. 특히 혁신적 개발 재원 조달 역시 2000년대 초반부터 그 논의가 점차 활발해져왔으며 최근에는 개발재원 논의에서 가장 뜨거운 이슈로 떠올랐다. 이러한 상황에서 논의를 생산적으로 발전시키기 위한 효과적 소통과 파트너십 구축을 위해서는 '혁신적 개발재원 조달' 개념에 관해 공통의 언어(common language) 를 마련해야 한다는 의견에 공감대가 형성되고 있다.

본 고에서는 혁신적 개발재원 조달 논의의 등장배경과 흐름을 살펴봄으로써 동 개념에서 '혁 신적'의 성격이 발전해오고 있음을 발견해냈다. 이를 통해 '혁신적 개념'의 패러다임이 어떻게 변 화해왔는지를 분석하였고, 그 가운데에서도 혁신적 성격이 가지고 있는 공통적 사항들을 파악하 였다. 개발재원 조달을 위해서 '혁신적' 성격을 도입하는 데 가장 중요한 것은 개발재원의 규모적 동원뿐만 아니라 개발영향을 극대화하기 위해 관련 수단과 메커니즘을 효과적으로 현명하게 활용 해야 한다는 것이다. 이를 통해 글로벌 개발과제를 지속가능한 방법으로 해결하는 것이 가장 궁 극적으로 지향해야 할 점일 것이다. 향후에도 동 논의를 지속적으로 발전시켜나가기 위해서는 혁 신적 개발재원 조달 개념에 대한 국제 사회의 합의를 만들어가는 과정이 필요할 것이며, 다양한 수단과 메커니즘의 실행을 통해 혁신적 성격을 발견해나가는 작업 또한 함께 진행되어 나가야 할 것이다. 


\section{〈참고문헌〉}

\section{[국내문헌]}

제 I 장

류승석. 2013. “국제사회의 혁신적 개발재원 논의와 우리나라 ODA에 주는 시사점" 『개 발협력 정책과 이슈』9호. 2013. 성남: 한국국제협력단

맹준호. 2014. "개도국의 지속가능한 개발목표(SDGs) 달성을 위한 혁신적 개발재원 논의". 원조와 개발 논단. 『한국의 개발협력』2014. 서울: 한국수출입은행

박수영, 오수현. 2015a. "Post-2015 체제의 개발재원 논의분석". 성남: 한국국제협력단 2015b. “제 3 차 개발재원총회와 아디스아바바 행동계획의 함의 분석”. 『개발과

이슈』24호. 성남: 한국국제협력단

오수현. 2015. “지속가능발전목표(SDGs) 달성을 위한 민간파트너십과 재원메커니즘”. 『국제개발협력』2015년 3호. 성남: 한국국제협력단

조은진. 2010. “혁신적 개발재원 논의 동향” 『한국의 개발협력』2010년 1호. 서울: 한국 수출입은행

\section{[국외문헌]}

Devfin Advisers. 2014. “Innovative Finance Gap Analysis”. Drottningholm: Devfin Advisers

Girishankar, Navin. 2009. "Innovating Development Finance: From Financing Sources to Financial Solutions". CFP Working Paper Series No.1. Washington, D.C: World Bank

Global Development Incubator \& Dalberg. 2014. "Innovative Financing for Development: Scalable Business Models that Produce Economic, Social, and Environmental Outcomes”. New York: Gloabal Development Incubator \& Dalberg Kharas, Homi. 2013. "Reimagining the Role of the Private Sector in Development”. Washington, D.C.: Brookings Institution

Lampert, Sam. 2016. "Overview of the Innovative Financing Landscape”. presented at Peer Learning Spotlight Event: Innovative Instruments for Working with and through the Private Sector in Development Co-operation, held in Copenhagen on Feb. 9th, 2016 
Leading Group on Innovative Financing for Development. 2012. "Peer review of existing innovative financing for development”. Paris: Leading Group on Innovative Financing for Development

2010. "Globalizing Solidarity: The Case for Financial Levies". Paris: Leading Group on Innovative Financing for Development

OECD. 2014. "Innovating to finance development”, Chapter 15, Part II,

Mobilising Resources for Sustainable Development, Development Co-operation Report 2014. Paris: OECD

. 2011. Busan Partnership for Effective Development Co-operation.

Fourth High Level Forum on Aid Effectiveness Outcome Document. Paris:

OECD

2009. Innovative Finance to Fund Development: Progress and Prospects. OECD Brief 2009. Paris: OECD

Sida. "Innovative Financing - Collaboration with the private \& public sector". Stockholm: Sida

The I-8 Group. 2009. "Innovative Financing for Development. The I- 8 Group

Leading Innovative Financing for Equity (L.I.F.E)”. New York: UN

The Technical Group. 2004. "Report of the Technical Group on Innovative

Financing Mechanisms”. September 2004. Paris: France

UN. 2015. "Outcome document of the Third International Conference on

Financing for Development: Addis Ababa Action Agenda”. New York: UN . 2011. "Resolution adopted by the General Assembly on 20 December

2010. 65/146. Innovative mechanisms of financing for development”. 4

February 2011. New York: UN

. 2009. "New York Declaration on action against hunger and poverty".

20th September 2004. New York: UN

2008. "Doha Declaration on Financing for Development: outcome document of the Follow-up International Conference on Financing for Development to Review the Implementation of the Monterrey Consensus". New York: UN 
_ 2003. "Monterrey Consensus of the International Conference on Financing for Development. The final text of agreement and commitments adopted at the International Conference on Financing for Development”. New York: UN

USAID. 2016. "Development Credit Authority (DCA) Portfolio Management Overview". presented at the Peer Learning Spotlight Event of Innovative Instruments for Working with and through the Private Sector in Development Co-operation, held in Copenhagen on Feb. 9th, 2016

World Bank. 2013. "Innovative finance for development solutions: Initiatives of the World Bank Group”. Washington, D.C: World Bank 2009. "Innovative Development Finance: From Financing Sources to Financial Solutions”. Washington, D.C: World Bank

\section{[웹사이트]}

http://www.leadinggroup.org/rubrique323.html 